\title{
Role of food availability in the bathymetric distribution of the starfish Marthasterias glacialis (Lamk.) on reefs of northern Portugal
}

\author{
FERNANDO TUYA ${ }^{1,2,3}$ and PEDRO DUARTE ${ }^{1,4}$ \\ ${ }^{1}$ CIIMAR, Rua dos Bragas 269, 4450-123 Porto, Portugal. \\ 2 BIOGES, Facultad de Ciencias del Mar, Universidad de Las Palmas de Gran Canaria, \\ 35017 Las Palmas de G.C., Canary Islands, Spain. E-mail: ftuya@yahoo.es \\ ${ }^{3}$ School of Natural Sciences, Centre for Ecosystem Management, \\ Edith Cowan University, Joondalup Drive, 6027 WA, Australia. \\ ${ }^{4}$ CIAGEB, Faculty of Science and Technology, University Fernando Pessoa, Porto, Portugal.
}

\begin{abstract}
SUMMARY: We examined whether the abundance and size of the starfish Marthasterias glacialis (Lamk.) exhibit a depthdependent partitioning on subtidal reefs. We tested the hypothesis that differences in food availability can result in habitat partitioning along a depth gradient. The abundance and size of $M$. glacialis was registered at 4 depth strata: $0-4 \mathrm{~m}, 4-8 \mathrm{~m}$, 8-12 m, and $>12 \mathrm{~m}$; we also recorded the number of food items that they were preying on. The abundance and size of $M$. glacialis decreased with depth. Mussels (Mytilus galloprivincialis) were the most preyed food item across all depth strata, followed by gastropods, sea urchins and barnacles; M. glacialis also consumed a significantly larger amount of mussels in feeding experiments compared with sea urchins and gastropods. The abundance of $M$. galloprivincialis beds decreased with depth. The clear link between the decrease in abundance and size of M. glacialis with depth and the decay of the most consumed prey (mussels) suggest that food availability may play an important role in the vertical distribution of this starfish, though wave-associated turbulence in the first few metres of the subtidal could also limit the abundance of M. glacialis.
\end{abstract}

Keywords: starfish, vertical distribution, segregation, food availability, spatial patterns, Portugal.

RESUMEN: EFECTO DE LA DISPONIBILIDAD ALIMENTICIA SOBRE LA DISTRIBUCIÓN BATIMÉTRICA DE LA ESTRELLA DE MAR MARTHASTERIAS GLACIALIS (LAMK.) EN ARRECIFES DEL NORTE DE PORTUGAL. - Examinamos si la abundancia y talla de la estrella de mar Marthasterias glacialis (Lamk.) exhibe una segregación batimétrica en arrecifes submareales. Contrastamos el modelo que predice que diferencias en la disponibilidad alimenticia puede resultar en una segregación del hábitat a lo largo de un gradiente batimétrico. La abundancia y talla de M. glacialis se registró sobre 4 estratos de profundidad: 0-4 m, 4-8 m, 8-12 m, y>12 m; además registramos el número de presas sobre las que estaban depredando. La abundancia y talla de M. glacialis decreció con la profundidad. Los mejillones (Mytilus galloprivincialis) fueron la presa más consumida, seguido de gasterópodos, erizos de mar y cirrípedos; $M$. glacialis también consumió una cantidad significativamente superior de mejillones en experiencias alimentarias en relación a erizos de mar y gasterópodos. La clara asociación entre la caída en profundidad de la abundancia y talla de $M$. glacialis y la caída de su presa más consumida (mejillones) sugiere que la disponibilidad alimentaria juega probablemente un papel importante en la distribución vertical de esta estrella de mar. No obstante, individuos marcados mostraron un movimiento a corto plazo mayor sobre un estrato somero que sobre un estrato profundo, y por tanto, la turbulencia asociada al oleaje en los primeros metros del medio submareal también pudiera afectar el patrón ecológico de M. glacialis con la profundidad.

Palabras clave: estrellas de mar, distribución vertical, segregación, disponibilidad alimentaria, patrones espaciales, Portugal.

\section{INTRODUCTION}

It has long been recognized that habitat partitioning among species, or individuals of a particular spe- cies, can occur on relatively small spatial scales due to sharp gradients in environmental conditions, food resources, and biotic interactions (Hutchinson 1959, Whittaker 1970). For example, on shallow subtidal 
reefs of temperate latitudes, the arrangement of sessile assemblages across a depth gradient has been widely described: algae typically dominate within the first few metres of the subtidal, while deeper areas are dominated by filter feeders (e.g. sponges, bryozoans) (Witman and Dayton 2001).

The bathymetric segregation of subtidal mobile megafauna can occur in response to biotic and abiotic processes, mainly gradients in environmental parameters (e.g. light, temperature, turbulence, sedimentation) that co-vary with depth, affecting the physiology and ecology (e.g. abundance, reproduction, aggregation) of marine organisms and the way they interact (Whittaker 1970, Denny 1988, Siddon and Witman 2003). A change in the abundance and size of subtidal mobile organisms with depth has been documented in response to food availability, particularly for invertebrates inhabiting soft bottoms that rely on the input of particulate organic matter as the main source of food (Gaymer et al. 2001, Steffens et al. 2006, Harriague and Albertelli 2007).

Asteroids (sea stars) have been largely recognized to play one of the most prominent ecological roles in benthic ecosystems on a variety of scales across temperate (Paine 1966) and tropical coasts (De'ath and Moran 1998). Marthasterias glacialis (Lamk.) is a conspicuous starfish inhabiting the intertidal and subtidal of the eastern Atlantic rocky coasts (Verling et al. 2003), including southern and southwestern Europe (Guillou 1996), as well as the Mediterranean (Savy 1987) and South Africa (Penney and Griffiths 1984). This invertebrate is a slow-moving predator that relies principally upon chemoreception and chance encounter to locate potential prey (Sloan 1980, Verling et al. 2003). Importantly, M. glacialis is capable of exploiting a wide range of prey resources, and plays a key role in community structure through predation. For example, in the Mediterranean it can control densities of the sea urchin Paracentrotus lividus (Gianguzza et al. 2009, Bonaviri et al. 2009), which is involved in the establishment of urchin-grazed barrens. Moreover, it can exert a profound control over mussel beds across temperate coasts of the Atlantic (Penney and Griffiths 1984, Verling et al. 2003, Little et al. 2009).

In this study, we considered whether the starfish Marthasterias glacialis is segregated by depth on subtidal rocky reefs off northern Portugal. We aimed to test (1) whether there are consistent differences in patterns of abundance and size with depth, and (2) whether these differences are related to differences in food availability with depth. To accomplish these goals, we combined a field survey encompassing a depth gradient across several reefs with indoor feeding consumption experiments (choice and non-choice) to test for patterns of food attractiveness among different prey. We additionally determined whether individuals showed different patterns of short-term movement between depth strata.

\section{MATERIALS AND METHODS}

\section{Study area}

The field study was carried out on 4 rocky (granitic) reefs covering depths from 0 to $16 \mathrm{~m}$ at Póvoa do Varzim $\left(41.38^{\circ} \mathrm{N}\right.$, northern Portugal, Atlantic Ocean) (Fig. 1) in July-September 2009. All reefs were exposed to the dominant NW and W oceanic swells. Reefs were stratified in 4 depth strata: 0-4 m, 4-8 m, 8-12 m, and >12 m.

\section{Field survey}

The abundance of the starfish Marthasterias glacialis was counted by a SCUBA diver in 5 replicate $3 \times 2 \mathrm{~m}$ $\left(6 \mathrm{~m}^{2}\right)$ belt transects at each depth stratum on each reef. Counts avoided vertical walls. Another diver measured, using a rule, the size (= the maximum tip-to-tip diameter; Verling et al. 2003) of 30 randomly selected individuals per depth stratum and reef. For each individual, we also recorded the prey item being handled at the time of collection (Penney and Griffiths 1984). Finally, the \% cover of benthic sessile taxa was recorded ( $n=8$ replicates) on each depth stratum using a $50 \times 50 \mathrm{~cm}$ quadrat $(0.25$ $\mathrm{m}^{2}$ ), following standard point-quadrat procedures with a grid of 121 points per quadrat. This is a rapid, nondestructive technique for assessing community structure and dominance of sessile biota (e.g. Fowler-Walker and Connell 2002). Sessile benthic taxa were grouped into 3 functional groups: Mytilus galloprivincialis mussels, turf algae and filter feeders (which included organisms such as anemones, sponges, bryozoans, etc).

To test for the consistency in the differences in the abundance and size among the 4 depth strata across reefs, we applied a mixed effect two-factor ANOVA, which incorporated the factors: (1) 'Reefs' (random

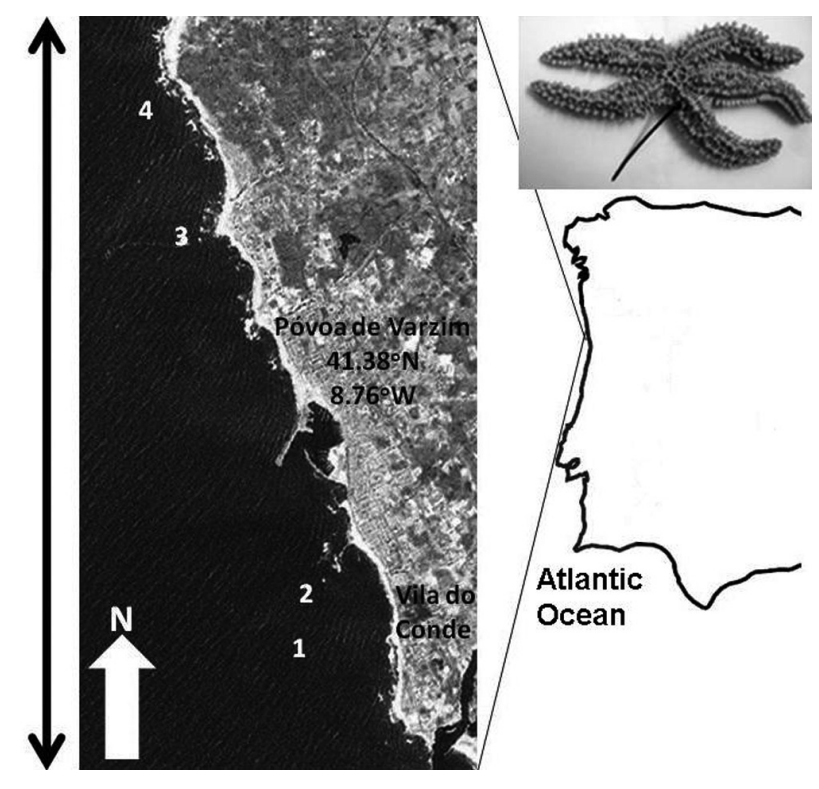

FIG. 1. - Map of the study area. Inserted (top-right panel) shows a tagged individual. 
factor with 4 levels) and (2) 'Depth' (fixed factor with 4 levels; orthogonal to 'Reefs'). Tukey pairwise comparisons were used to resolve differences in abundance and size among depth strata for each reef. Differences in the percentage of prey items being handled among reef strata at the time of collection were tested using a $\chi^{2}$ test. Pearson product-moment correlation tested the significance of the relation between the abundance of $M$. glacialis and M. galloprivincialis mussels with depth.

\section{Dispersion patterns across the vertical axis: tagging experiments}

A tagging experiment was conducted to determine whether there was a difference in the short-term dispersion pattern between a shallow and a deep stratum. A total of 100 individuals were collected and tagged using external nylon tags drilled through the central disc using a hypodermic needle (Fig. 1. - inserted panel, for details, see Clemente et al. 2007). A preliminary study in aquaria demonstrated that tagged individuals did not suffer any mortality as a result of tagging after 10 days. Fifty tagged individuals were released at $c a .4 \mathrm{~m}$ depth, while the other 50 individuals were released at $c a .11 \mathrm{~m}$ depth on the same reef. All tagged individuals were adjacent $(\sim 1 \mathrm{~m})$ to mussel beds. Individuals were searched after 2 days. Using a metric tape, we recorded the linear distance travelled relative to the spot where the individuals were released, as well as the depth of each individual. Depths were further adjusted for tidal differences between the 2 days. Differences in the linear displacement between the 2 strata $(4 \mathrm{~m}$ vs. $11 \mathrm{~m}$ ) were tested by means of a $t$ test.

\section{Food consumption: choice and non-choice feeding experiments}

Experimental prey consumption studies were conducted in a closed-circuit seawater facility at CIIMAR (University of Porto). Aerated tanks (plastic containers $35 \mathrm{~cm}$ long $\times 25 \mathrm{~cm}$ wide $\times 25 \mathrm{~cm}$ high) were supplied with circulating natural seawater $\left(16^{\circ} \mathrm{C}\right)$ at ambient light

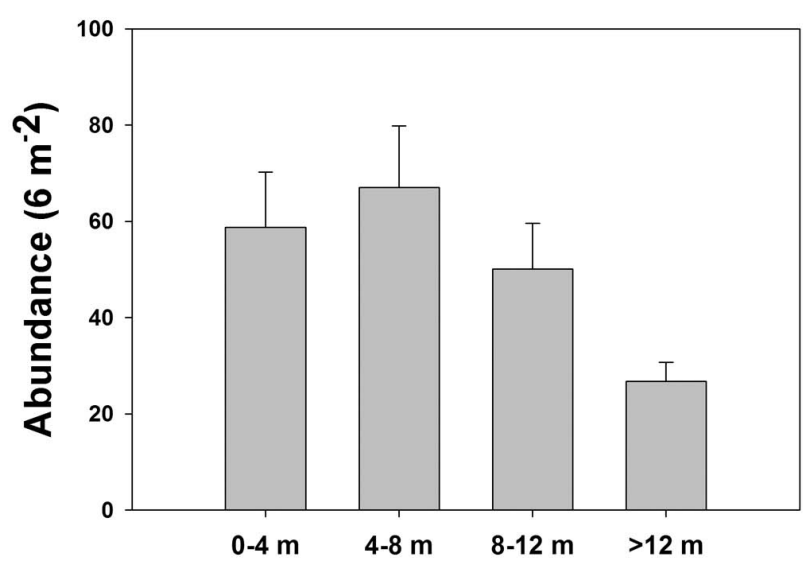

FIG. 2. - Abundance $\left(6 \mathrm{~m}^{-2}\right)$ of the starfish $M$. glacialis on each depth stratum. Error bars are $+\mathrm{SE}$ of means $(\mathrm{n}=20)$. conditions. The main prey items found in the surveys, the mussel Mytilus galloprivincialis and the sea urchin Paracentrotus lividus, as well as a conspicuous gastropod inhabiting shallow rocky reefs (Gibulla spp.), were selected. All animals were collected on shallow subtidal reefs at Amorosa (northern Portugal) and transported immediately to the seawater facility, where they were stored in an aerated 600-L tank. The starfishes were allowed to acclimate to the experimental system for 24 $\mathrm{h}$ prior to the experimental procedures without food to clear the gut contents, in order to reduce the possibility that recently consumed food would influence consumption. Two sets of trials were set up: no-choice and choice feeding experiments. In both cases, 1 starfish $(8-10 \mathrm{~cm}$ maximum tip-tip diameter) was placed in each tank. For the no-choice experiment, either 4 mussels (M. galloprivincialis, $45-50 \mathrm{~mm}$ total length), 4 sea urchins ( $P$. lividus, $35-55 \mathrm{~mm}$ of test diameter) or 4 gastropods (Gibulla spp., 10-16 $\mathrm{mm}$ total length from the base of the aperture to the tip of the shell) were supplied to each tank, with 4 replicated tanks per treatment (overall a total of 16 prey of each species were supplied). For the choice experiment, all paired combinations of 4 individuals of each prey (= 4 mussels +4 urchins, 4 mussels +4 gastropods, and 4 urchins +4 gastropods) were added to 3 replicated tanks. Moreover, 3 replicated tanks containing 4 individuals of each prey ( $=4$ mussels +4 urchins +4 gastropods) were also included, for a total of 36 individuals of each prey. In both cases, experimentation occurred over 3 days, providing sufficient time to detect predation effects (Gianguzza et al. 2009). At the end of the experimental period, the number of consumed mussels, sea urchins and gastropods was annotated for each tank, and each individual prey was scored as consumed or alive. Differences in consumption of individual starfishes were tested with logistic regression using a $\chi^{2}$ test (Hosmer and Lemeshow 2000).

\section{RESULTS}

\section{Field survey}

The mean abundance of $M$. glacialis was lower at the deepest depth stratum $(>12 \mathrm{~m})$ than at the other depth strata (Fig. 2), while the mean size decreased progressively with depth (Fig. 3). In both cases, we detected some inconsistencies in these patterns from reef to reef ('Reefs $\times$ Depth', $P<0.001$; Table 1 ). On the 4 reefs, individuals were typically more abundant and larger at the shallowest 2 depth strata (0-4 $\mathrm{m}$ and 4-8 $\mathrm{m})$ than at the deepest strata (>12 m): pairwise comparisons for 'Reefs $x$ Depth' indicated that mean abundances and sizes at $0-4 \mathrm{~m}$ were larger than at $>12 \mathrm{~m}$ on all reefs, while mean abundances and sizes at $4-8 \mathrm{~m}$ were larger than at $>12 \mathrm{~m}$ at 3 and 2 of the 4 reefs, respectively.

Of the 480 individuals we examined across all depth strata and reefs, 187 were preying on food items. Overall, mussels (Mytilus galloprivincialis) were quantitatively the most preyed item at all depth 


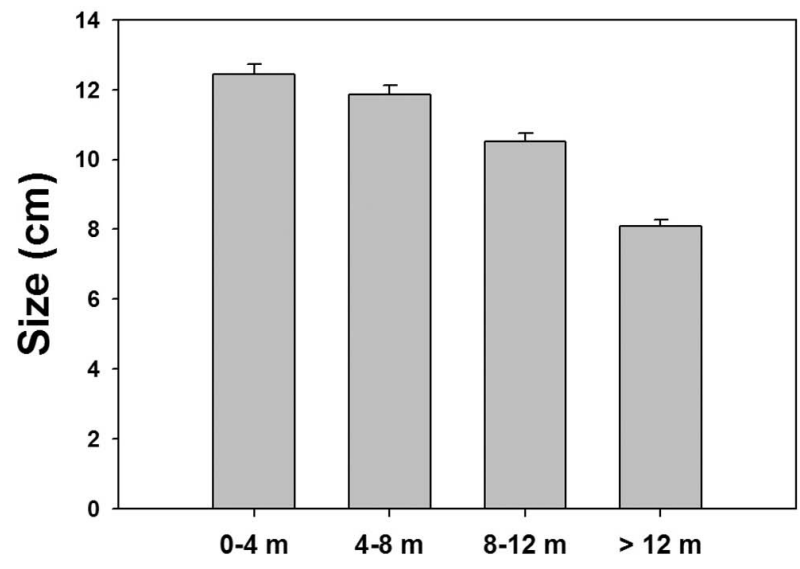

FIG. 3. - Size of the starfish M. glacialis on each depth stratum. Error bars are $+\mathrm{SE}$ of means $(\mathrm{n}=120)$.

TABLE 1. - Results of 2-way ANOVA testing for differences in the abundance and size of the starfish $M$. glacialis among 4 depth strata across 4 reefs.

\begin{tabular}{lcrccrrr}
\hline & \multicolumn{4}{c}{ Abundance } & \multicolumn{3}{c}{ Size } \\
& Df & MS & F & p & MS & F & p \\
\hline Reefs & 3 & 43.75 & 7.95 & 0.0002 & 287.21 & 40.08 & 0.0003 \\
Depth & 3 & 20.55 & 0.60 & 0.63 & 284.25 & 3.28 & 0.0767 \\
Reefs x Depth & 9 & 33.70 & 6.12 & 0.0002 & 86.60 & 12.08 & 0.0001 \\
Residual & 64 & 351.98 & 5.49 & & 3324.80 & 7.16 & \\
\hline
\end{tabular}

strata (accounting for $c a .97 \%$ of the total, Fig. 4), followed by prosobranch gastropods (ca. $2 \%$ ), sea urchins (Paracentrotus lividus, (ca. 0.5\%) and barnacles (ca. $0.5 \%$ ) (Fig. 4). This result should be taken with caution, because it is possible that mussels take a starfish a longer period of time to consume, so the likelihood of counting mussel consumption events might have been artificially increased. Consumption of food items, particularly mussels, progressively decreased with depth (Fig. 4); we detected a significant decrease in consumption on the $>12 \mathrm{~m}$ stratum in comparison with the $0-4 \mathrm{~m}\left(\chi^{2}=20.36, P<0.001\right), 4-8 \mathrm{~m}\left(\chi^{2}=19.74\right.$, $P<0.001)$ and $8-12 \mathrm{~m}\left(\chi^{2}=10.98, P<0.01\right)$ strata.

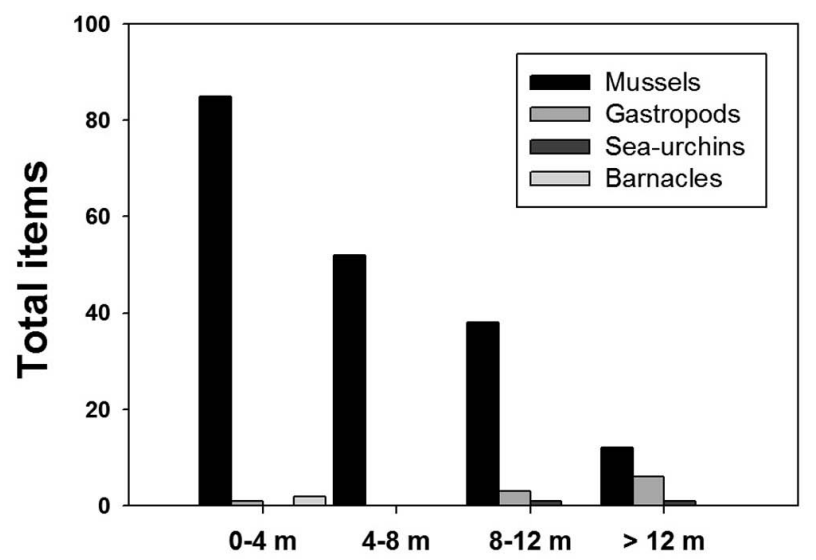

FIG. 4. - Total number of prey items found under the mouth of 30 randomly selected individuals at each depth stratum per reef $(n=120)$.

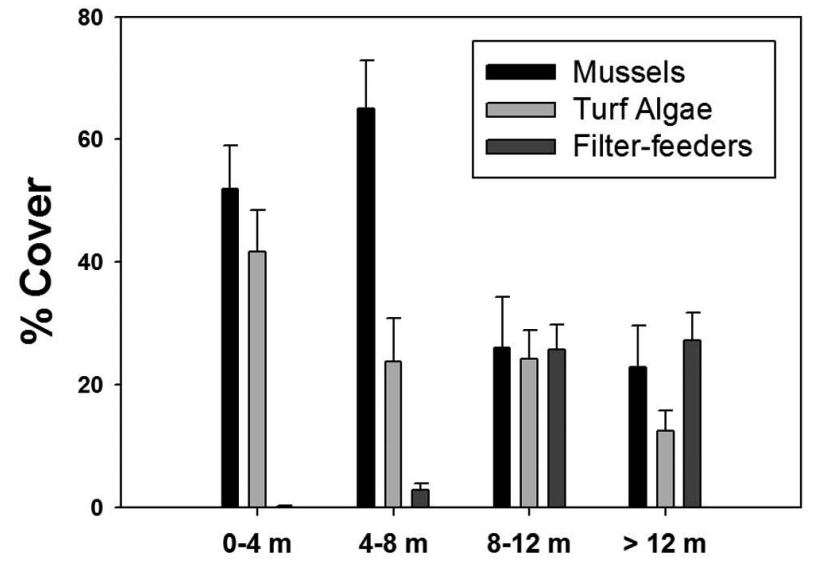

FIG. 5. - Coverage $(\%)$ of functional groups on each depth strata. Error bars are + SE of means $(n=32)$.

The abundance of Mytilus galloprivincialis beds also decreased with depth (Fig. 5), from a mean cover $>50 \%$ at the shallowest 2 strata to $<25 \%$ at the 2 deepest strata, and the cover of turf algae also decreased. In contrast, the cover of filter feeders progressively increased in abundance with depth (Fig. 5). The abundances of $M$. glacialis and $M$. galloprivincialis were significantly correlated across the study area $\left(r_{\mathrm{s}}=0.67\right.$, $P<0.0001)$.

\section{Dispersion patterns across the vertical axis: tagging experiments}

Only 31 individuals were recaptured (6 of the 50 individuals tagged at the shallow stratum and 25 of the 50 tagged at the deep stratum). Shallow-tagged individuals showed a greater linear displacement than deeptagged individuals (Fig. 6a, $t$ test $=2.1834, P=0.035$ ). In general, shallow-tagged individuals showed a net displacement towards deeper areas of the reef, while deep-tagged individuals remained at the same depth (Fig. 6b).

\section{Food consumption: choice and non-choice feeding experiments}

Marthasterias glacialis consumed a significantly larger amount of mussels than of the other 2 types of prey for both the no-choice (Fig. $7 \mathrm{a}, \chi^{2}=61.10$, $P<0.00001)$ and the choice feeding experiment (Fig. $\left.7 \mathrm{~b}, \chi^{2}=59.32 P<0.00001\right)$.

\section{DISCUSSION}

\section{Bathymetric segregation on subtidal reefs: role of food availability}

Gradients in the abundance and size patterns of echinoderms with depth have been previously reported for species inhabiting the lower intertidal and subtidal zones of temperate coasts (Larson 1968, Freeman 

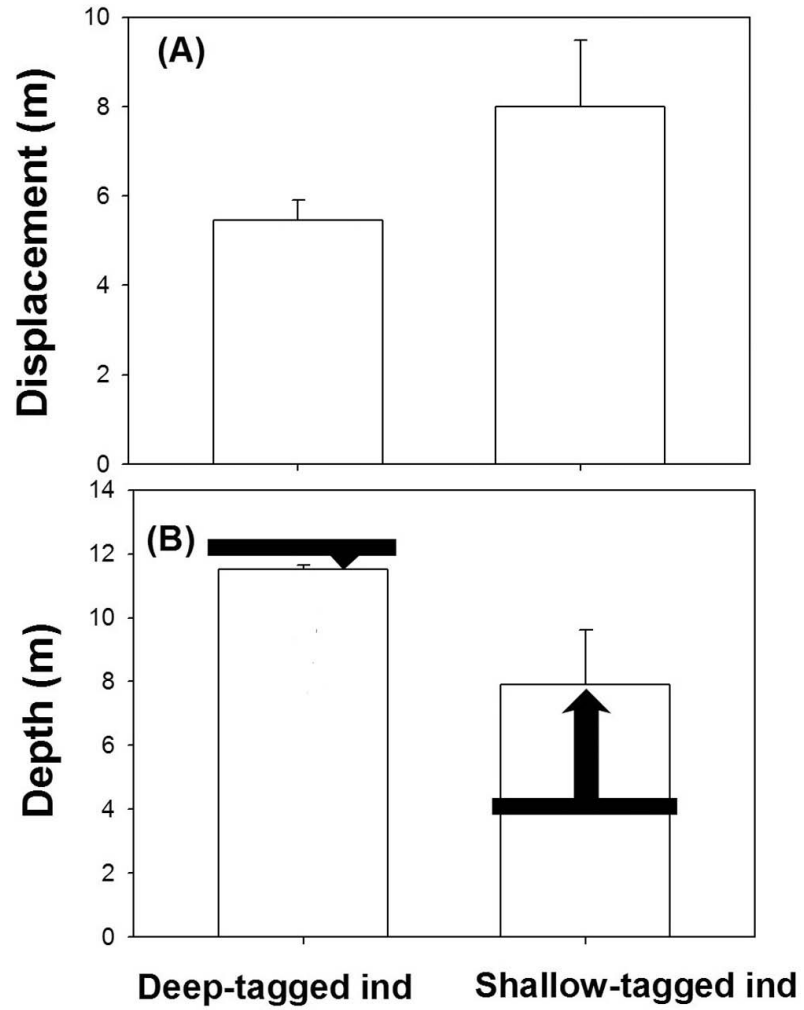

FIG. 6. - Movement of tagged M. glacialis. (a) Linear displacement, (m) and (b) depth of shallow- and deep-tagged individuals after 2 days. The arrows indicate the net movement of individuals across the vertical axis from the depth where tagged individuals were released (black horizontal lines). Error bars are $+S E$ of means ( $n=6$ for shallow-tagged individuals and $n=25$ for deep-tagged individuals).

2003), and even the deep sea (Mercier and Hamel 2008). These within-species differences in abundance and size patterns have been attributed to the interplay between food, competition and predation, recruitment, and physical factors such as hydrodynamic forces (Doering and Phillips 1983, Freeman 2003). Our study revealed that food availability appears to play an important role in determining the vertical patterns of abundance and size of the starfish Marthasterias glacialis on subtidal rocky reefs off northern Portugal. The clear association between the decrease in abundance and size of $M$. glacialis with depth and the decay with depth of the most consumed-and attractive-prey (mussels) suggest that food availability plays an important role in the vertical distribution pattern of this starfish. Typically, a larger availability of food improves fitness through enhanced growth and reproductive potential of species (for a review see White 2008), including benthic invertebrates (e.g. dos Santos et al. 2008). Concentration of food resources in small patches tends to aggregate species on, or immediately adjacent to, their resources, particularly for subtidal mobile predators. Large aggregations of starfishes of the genus Asterias have been reported on super-abundant food resources such as mussels in the intertidal and the shallow subtidal (Larsson 1968, Sloan and Aldridge 1981, Gaymer et

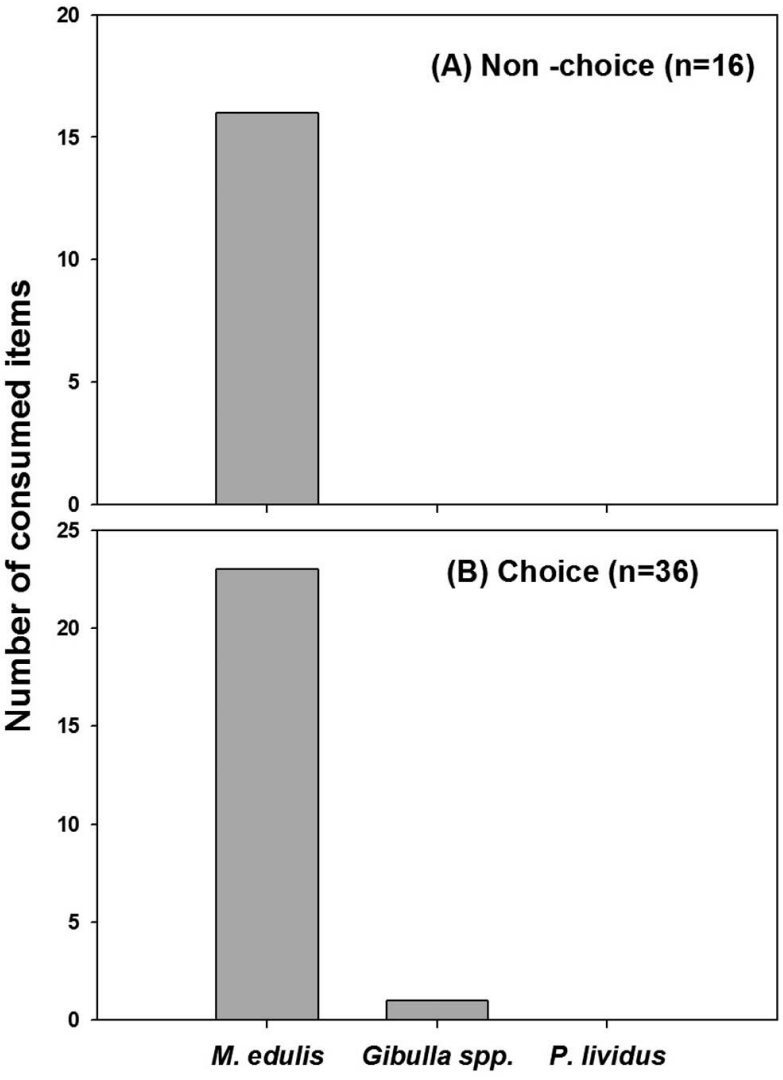

FIG. 7. - Number of consumed preys for (a) no-choice and (b) choice feeding experiments.

al. 2001). For example, maximum densities per reef of

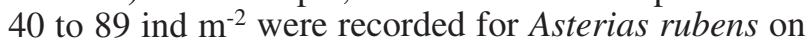
British coasts (Sloan and Aldridge 1981); these large concentrations were associated with the local presence of a super-abundant food source: $M$. galloprivincialis. This range of density values ( 40 to 89 ind $\mathrm{m}^{-2}$ ) is within the same range as those observed for $M$. glacialis in northern Portugal.

We lack data, however, to rule out the possibility that recruitment of $M$. glacialis in the study area may differ between the shallow and deep reef strata. The mean size of the population decreased with depth, so it could be possible that recruitment mainly occurred in the deep strata. This is, however, unlikely. First, survivorship of $M$. glacialis larvae decreases with an increase in the barometric pressure of the water column, and therefore with depth (Benitez-Villalobos et al. 2006). Second, recruits of M. glacialis have been previously located under boulders at the northern distribution edge of the rocky intertidal (Verling et al. 2003). Recruits of M. glacialis, like those of other asteroids, behave cryptically within complex structural habitats. Predation of this starfish may be greater on the deep strata. Predation is also unlikely to contribute to the observed patterns, since no previous studies have pointed out a significant predation pressure on the distribution and abundance patterns of $M$. glacialis in the Iberian Peninsula. In this regard, the predators, 
such as the starfish Luidia ciliaris (Philippi), the crabs Hyas araneus (L.) and Cancer pagurus (L.), and the sunstars Solaster endeca (L.) and Crossaster papposus (L.), identified in the northern distribution range of this species (Ireland, Ramsay et al. 2000, Verling et al. 2003) are not present, or are at very low densities, across continental Portugal (Rodrigues et al. 2008). Moreover, these predators were relatively conspicuous in the intertidal, but at very low densities in the subtidal (Verling et al. 2003).

The consistent bathymetric segregation detected by our study contrasts, however, with the lack of differences in the abundance of $M$. glacialis in the shallow subtidal of Ireland (Verling et al. 2003); individuals were considerably more abundant in the intertidal, as a result of the presence of a preferred habitat (a boulder field) relative to the subtidal, where soft bottoms dominated. Moreover, patterns of vertical segregation in Ireland were inconsistent from site to site (Verling et al. 2003), while the vertical pattern in abundance and size of $M$. glacialis detected by our study was consistent among reefs. However, we observed differences in the magnitude of differences in abundance and size among depth strata from reef to reef, most likely as a result of differences in the structural complexity among reefs. It is also worth noting that, while in northern Portugal mussels constituted the most consumed prey item across all depth strata, the diet composition varied notably between depths in Ireland. These considerations further reinforce the notion that mussel availability determined the vertical patterns in the abundance and size of M. glacialis in the study area.

Patterns in reef-associated assemblages are frequently affected by natural hydrodynamic forces (Siddon and Witman 2003). Mobile organisms inhabiting wave-swept shores are vulnerable to displacement by drag and lift forces induced by waves in the first few meters of the subtidal; this is particularly important on shores exposed to waves. The study area is routinely affected by large oceanic swells that easily reach up to 5-6 m (www.hidrografico.pt). Abundances of $M$. glacialis at the shallowest reef stratum (0-4 m) were not larger than abundances at the following stratum $(4-8 \mathrm{~m})$. Shallow-tagged individuals showed a greater displacement than deep-tagged individuals, as well as a general movement towards deeper areas of the reef. These results might suggest that individuals search rapidly for shelter from wave-induced forces, and reinforce observations that suggest that strong surge can affect the abundance patterns of starfishes (Menge 1974). Though these results are hard to interpret, particularly as a result of the unbalanced number of recaptured individuals from the 2 depth strata, these outcomes provide evidence of the potential role played by wave-associated turbulence in differences in the ecological pattern of M. glacialis with depth. In any case, more experimental evidence using quantitative manipulations are needed to test this hypothesis rigorously.

\section{Biogeographic considerations}

Abundances detected by our study (ca. 20-70 ind $\mathrm{m}^{-2}$ ) on subtidal reefs off northern Portugal are considerably greater than those observed in other places across the distribution range of $M$. glacialis: $c a .0-2$ ind $\mathrm{m}^{-2}$ near its northern range edge (Ireland, Verling et al. 2003), ca. 0-0.33 ind $\mathrm{m}^{-2}$ near its southern range edge (Canary Islands, Ortega et al. 2009), and 0-0.01 ind $\mathrm{m}^{-2}$ in the Mediterranean (Gianguzza et al. 2009). Because our study area is geographically situated near to its centre of distribution, this result might suggest that $M$. glacialis fits an 'abundant centre' pattern (Sagarin et al. 2002), which leads to the expectation that the abundance of a species peaks at its centre of distribution and declines towards the range limits. Though the 'abundant centre' hypothesis has been demonstrated for some marine species (e.g. Tuya et al.2008), there is no consensus on the mechanistic explanations of such patterns. A number of different mechanisms have indeed been proposed that could support an abundant centre distribution (Sagarin et al. 2002). In theory, there is an optimal fitness associated with favourable environmental conditions near the range centre. Our study suggests a connection between large food availability and large abundances at the centre of the distribution range of M. glacialis. This mechanism does not necessarily rule out alternative explanations, but calls attention to food availability as a parsimonious, simple, explanation for 'abundant centre' patterns, even though it has not been proposed before (Sagarin et al. 2002).

\section{ACKNOWLEDGEMENTS}

We gratefully thank F. Arenas and I. Bertocci for helping with the setting up and maintenance of the feeding experiment. Two anonymous reviewers helped to improve a previous draft of this manuscript.

\section{REFERENCES}

Benitez-Villalobos F., Tyler P.A., Young C.M. 2006. Temperature and pressure tolerances of embryos and larvae of the Atlantic sea stars Asterias rubens and Marthasterias glacialis (Echinodermata: Asteroidea): Potential for deep-sea invasion from North Atlantic. Mar. Ecol. Prog. Ser. 314: 109-117.

Bonaviri C., Vega-Fernández T., Badalamenti F., Gianguzza P.,Di Lorenzo M., Riggio S. 2009. Relative role of fish vs. starfish predation in controlling sea urchin populations in Mediterranean rocky shores. Mar. Ecol. Prog. Ser. 382: 129-138.

Clemente S., Hernández J.C., Brito A. 2007. An external tagging technique for the long-spined sea urchin Diadema aff. antillarum. J. Mar. Biol. Ass. UK. 87: 777-779.

De'ath G., Moran P.J. 1998. Factors affecting the behaviour of crown of thorns starfish (Acanthaster planci) on the Great Barrier Reef. 1. Patterns of activity. J. Exp. Mar. Biol. Ecol. 220: 83-106.

Denny M.W. 1988. Biology and the mechanisms of wave-swept environment. Princeton University Press, New York.

Doering P.H., Phillips D.W. 1983. Maintenance of the shore-level size gradient in the Marine Snail Tegula funebralis (A. Adams): Importance of behavioural responses to Light and Sea Star Predators. J. Exp. Mar. Ecol. 67: 159-173.

Dos Santos G.A.P., Derycke S., Fonseca-Genevois V.G., Coelho 
L.C.B.B., Correia M.T.S., Moens T. 2008. Differential effects of food availability on population growth and fitness of three species of estuarine, bacterial-feeding nematodes. J. Exp. Mar. Biol. Ecol. 355: 27-40.

Fowler-Walker M.J., Connell S.D. 2002. Opposing states of subtidal habitat across temperate Australia: consistency and predictability in kelp canopy-benthic associations. Mar. Ecol. Prog. Ser. 240: 49-56.

Freeman S.M. 2003. Size-dependent distribution, abundance and diurnal rhythmicity patterns in the short-spined sea urchin Anthocidaris crassispina. Est. Coast. Shelf. Sci. 58: 703-713.

Gaymer C.F., Himmelman J.H., Johnson L.E. 2001. Distribution and feeding ecology of the sea stars Leptasterias polaris and Asterias vulgaris in the northern Gulf of St Lawrence, Canada. J. Mar. Biol. Assoc. UK 81: 827-843.

Gianguzza P., Bonaviri C., Guidetti P. 2009. Crushing predation of the spiny star Marthasterias glacialis upon the sea urchin Paracentrotus lividus. Mar. Biol. 156: 1083-1086.

Guillou M. 1996. Biotic and abiotic interactions controlling starfish outbreaks in the Bay of Douarnenez, Brittany, France. Oceanol. Acta 19: 415-420.

Harriague A.C., Albertelli G. 2007. Environmental factors controlling macrofaunal assemblages on six microtidal beaches of the Ligurian Sea (NW Mediterranean). Est. Coast. Shelf Sci. 73: 8-16.

Hosmer D.W., Lemeshow S. 2000. Applied logistic regression. John Wiley and Sons, New York.

Hutchinson G.E. 1959. Homage to Santa Rosalia, or why are there so many kinds of animals? Am. Nat. 93: 145-159.

Larson B.A.S. 1968. Scuba-studies on vertical distribution of Swedish rocky-bottom echinoderms. A methodological study. Ophelia 5: 137-156.

Little C., Williams G., Trowbridge C.D. 2009. The biology of rocky shores (second edition). Oxford Univ. Press, Oxford.

Menge B.A. 1974. Effect of wave action and competition on brooding and reproductive effort in the sea star Leptasterias hexactis. Ecology 55: 84-93.

Mercier A., Hamel J.F. - 2008. Depth-related shift in life history strategies of a brooding and broadcasting deep-sea asteroid. Mar. Biol., 156: 205-223.

Ortega L., Tuya F., Haroun R.J. 2009. The sea urchin Diadema antillarum Phillipi, 1845 influences the diversity and composition of the mobile mega-invertebrate community on rocky bottoms off the Canary Archipelago. Rev. Biol. Mar. 44: 489-495.

Paine R.T. 1966. Food web complexity and species diversity. Am. Nat. 100: 675-676.
Penney A.J., Griffiths C.L. 1984. Prey selection and the impact of the starfish Marthasterias glacialis and other predators on the mussel Choromytilus meridionalis. J. Exp. Mar. Biol. Ecol. 75: 19-36.

Ramsay K., Turner J.R., Vize S.J., Richardson C.A. 2000. A link between predator density and arm loss in the starfish Marthasterias glacialis and Asterias rubens. J. Mar. Biol. Ass. UK 80: 565-566.

Rodrigues N.V., Maranhão P., Oliveira P., Alberto J. 2008. Guia de Espécies Submarinas, Portugal - Berlengas. Edição Instituto Politécnico de Leiria, Leiria.

Sagarin R.D., Gaines S.D. 2002. The 'abundant centre' distribution: to what extent is it a biogeographical rule? Ecol. Lett. 5: 137-147.

Savy S. 1987. Activity pattern of the sea star, Marthasterias glacialis in Port-Cros Bay (France, Mediterranean Coast). P.S.Z.N.I. Mar. Ecol. 8: 97-106.

Siddon C.E., Witman J.D. 2003. Influence of chronic, low-level hydrodynamic forces on subtidal community structure. Mar. Ecol. Prog. Ser. 261: 99-110.

Sloan N.A. 1980. Aspects of the feeding biology of asteroids. Oceanogr. Mar. Biol. Annu. Rev. 18: 57-124.

Sloan N.A., Aldridge T.H. 1981. Observations on an aggregation of the starfish Asterias rubens L. in Morecamble Bay, Lancashire, England. J. Nat. Hist. 15: 407-418.

Steffens M., Piepenburg D., Schmid M.K. 2006. Distribution and structure of macrobenthic fauna in the eastern Laptev Sea in relation to environmental factors. Polar Biol. 29: 837-848.

Tuya F., Wernberg T., Thomsen M.S. 2008. Testing the 'abundant centre' hypothesis on endemic reef fishes in south-western Australia. Mar. Ecol. Prog. Ser. 372: 225-230.

Verling E., Crook A.C., Barnes D.K.A., Harrison S.S.C. 2003. Structural dynamics of a sea-star (Marthasterias glacialis) population. J. Mar. Biol. Ass. UK 83: 583-592.

Whittaker R.H. 1970. Communities and Ecosystems. Macmillan, New York.

White T.C.R. 2008. The role of food, weather and climate in limiting the abundance of animals. Biol. Rev. 83: 227-248.

Witman J.D., Dayton. P. 2001. Rocky subtidal communities. In: Bertness M.D., Gaines S.D., Hay M.E. (eds.), Marine Community Ecology, pp. 329-336, Sinauer Associates, Sunderland, Massachusetts.

Scient. ed.: J.S. Troncoso

Received January 19, 2011. Accepted April 4, 2011.

Published online October 28, 2011. 